\title{
Determination of Pozzolanic Activity for Using Natural Zeolite Analcime in Sustainability Additive Cement Products
}

\author{
Yasemin AKGÜN \\ Department of Renewable Energy, Ordu University, Ordu, Turkey
}

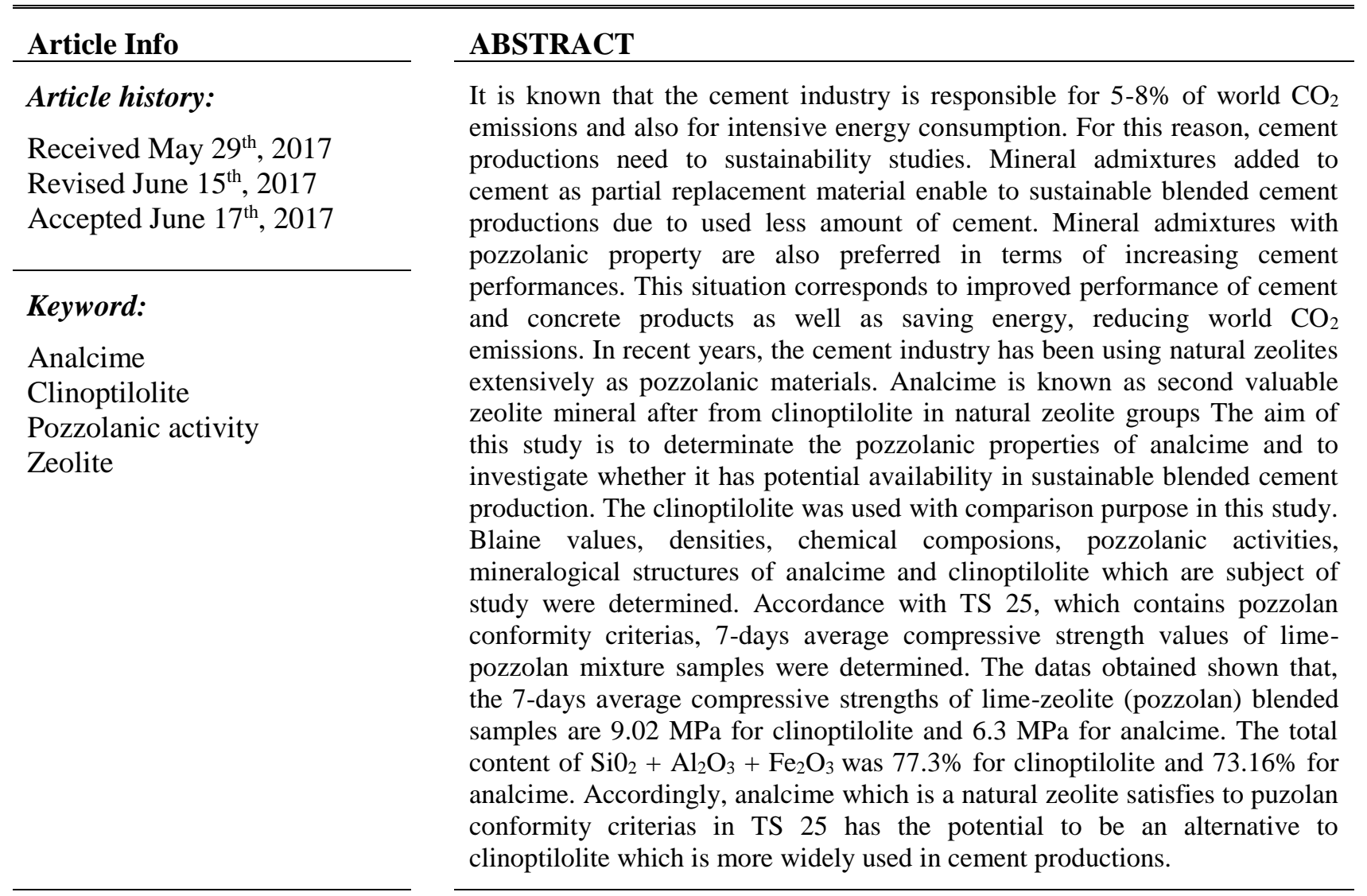

\section{Corresponding Author:}

Yasemin Akgün,

Departement of Renewable Energy,

Ordu University,

Ordu, Turkey

Email: yakgun@odu.edu.tr

\section{Introduction}

Cement is a construction material that needs to sustainability studies due to the decrease of non-renewable energy resources and the increase of $\mathrm{CO} 2$ emissions in the world. The easiest solution in sustainability studies is to produce blended cement by using pozzolans. Nowadays, the use of pozzolans which are substituted by cement has become very popular. The use of portland cement in a lesser amount leads to less energy consumption and less CO2 emissions. Thus, more environmentalist, energy saving, economical and sustainable cement productions can be possible. Also, the pozzolans with high activity affect positively to performances of mortar/concrete.

Pozzolans are defined as materials with silica and alumina. They have either any or very low binding property on their own. But, in the fine grained state, they are capable of exhibiting hydraulic binding when combined 
with calcium hydroxide in hydrous medium. Pozzolanic activity is defined as how much can provide reacting with slaked lime and water of pozzolanic materials and how much binding it can provide [1].

In other words, pozzolanic activity can be defined as the ability to react with $\mathrm{Ca}(\mathrm{OH}) 2$ of active silica which is in the pozzolan. At the end of this reaction the amount of portlandite $(\mathrm{Ca}(\mathrm{OH}) 2)$ is reduced, calcium silicate hydrate $(\mathrm{CSH})$ is increased [2]. To determine the pozzolanic activity, various chemical and mechanical experiments were included in the standards [3,4,5]. With chemical experiments, silica and $\mathrm{Ca}(\mathrm{OH}) 2$ are determined qualitatively and quantitatively. In mechanical experiments, it is determined whether pozzolans have active silica by determining flexural and compressive strengths of mortars produced with pozzolans mixed with lime or cement [6].

It is known that, zeolites have used as pozzolanic additives in mortar and concrete productions. The natural zeolites formed by the alteration of the vitric pyroclastic deposits are more reactive materials than the fly ash and furnace slags between mineral additives [7]. Zeolites contribute to the formation of cement-like hydrated products during the hydration of cement and to $\mathrm{Ca}(\mathrm{OH}) 2$ consumption occurred during the hydration process. So, zeolites improve performances of mortar/concrete [8]. Analcime is known as second valuable zeolite mineral after from clinoptilolite in natural zeolite groups. Analcime is a feldspathite mineral with a very large amount of hydrated sodium aluminosilicate $(\mathrm{Na}(\mathrm{AlSi} 2 \mathrm{O} 6) . \mathrm{H} 2 \mathrm{O})$ in its structure. The clinoptilolite is a natural zeolitic mineral species with chemical formula (Na3K3) (Al6Si30O72) 24H2O, which is rich in silica and contains alkali and earth alkaline cations [9].

Despite the large number of studies on pozzolanic activity of clinoptilolite in the literature, studies on that of analcime are very limited [10,11]. This study has been carried out in order to provide actively using of local and natural resources that could contribute to the sustainability of cement. The use of such natural additives with optimum values may be possible with scientific research outputs. So, the aim of this study is to determinate the puzolanic properties of analcime and to investigate whether it has potential availability in sustainable blended cement production. The clinoptilolite was used with comparison purpose in this study.

\section{Materials and Methods}

\subsection{Materials}

In experimental studies, the clinoptilolite and analcime which are natural zeolite minerals were used as replaced material by cement. The analcime and clinoptilolite were obtained from Ordu/Perşembe and Manisa/Gördes regions in Turkey, respectively. The two different natural zeolite samples were obtained by grinding from zeolite rocks in a ball mill. As a fineness parameter, in accordance with ASTM C430 [12] material percentage passing from $45-\mu \mathrm{m}$ was used. In pozzolanic activity tests, CEN standard sand which has preferably round granulated and characterized by a natural silica sand content of at least $98 \%$ silica dioxide according to TS EN 196-1 [13] standard was used. In lime-pozzolan mixtures, slaked lime $(\mathrm{Ca}(\mathrm{OH}) 2)$ as specified in TS 25 [5] was used. In the production of the samples, water which does not contain organic matter and mineral salts which may be harmful were used.

\subsection{Methods}

The specific surface, density, chemical composition, mineralogical structure of the materials used as pozzolan have an important effect on pozzolanic activity. The following methods were used for the determination of these parameters effected on pozzolanic activity of natural zeolites used in the study. Additionally, the determination method of pozzolanic activities of natural zeolites was mechanical experiment method which is determined by average compressive strengths of lime-pozzolan mortars.

Firstly, the physical properties of the natural zeolites were determined. The densities were determined according to TS EN 197-1 [14]. The specific surface (Blaine) were determined according to TS EN 196-6 [15]. X-Ray Diffraction (XRD) Analysis was performed to determine the chemical composition of natural zeolites. SEM views were also obtained using a Scanning Electron Microscope. The mineralogical structures of natural zeolites were determined by using XRD analysis. And then, the pozzolanic activities of natural zeolites were determined according to TS 25 .

\subsection{Preparation of the Samples and Tests on Pozzolanic Activity}

In TS 25, the pozzolanic activity test is defined as a characteristic determined in terms compressive strength of the mortar obtained by mixing natural pozzolan which is grinded at a certain fineness with water, standard 
sand and calcium hydroxide $\left(\mathrm{CaOH}_{2}\right)$. The amounts of materials required to prepare three test samples for tests on pozzolanic activity are given in Table 1.

Table 1 . The amounts of materials for tests on pozzolanic activity

\begin{tabular}{|c|c|c|c|}
\hline & & \multicolumn{2}{|c|}{ The amounts for tests } \\
\hline \multicolumn{2}{|c|}{ TS 25} & Clinoptilolite & Analcime \\
\hline $\begin{array}{l}\text { Slaked } \\
\text { lime } \\
\left(\mathrm{CaOH}_{2}\right)\end{array}$ & $150 \mathrm{gr}$ & $150 \mathrm{gr}$ & $150 \mathrm{gr}$ \\
\hline Pozzolan & $\begin{array}{l}2 \mathrm{x} 150 \mathrm{x} \\
\text { (pozzolan } \\
\text { density } \\
/ \mathrm{CaOH}_{2} \\
\text { density) }\end{array}$ & $\begin{array}{l}2 \times 150 \times(2.11 / 2.15)= \\
294.42 \mathrm{gr}\end{array}$ & $\begin{array}{l}2 \times 150 \times(2.28 / 2.15) \\
=318.14 \mathrm{gr}\end{array}$ \\
\hline $\begin{array}{l}\text { Standard } \\
\text { sand }\end{array}$ & $1350 \mathrm{gr}$ & $1350 \mathrm{gr}$ & $1350 \mathrm{gr}$ \\
\hline Water & $\begin{array}{l}0.5 \times(150+ \\
\text { pozzolan })\end{array}$ & $\begin{array}{l}0.5 \mathrm{x}(150+294.42) \\
=222.21 \mathrm{gr}\end{array}$ & $\begin{array}{l}0.5 \mathrm{x}(150+318.14) \\
=234.07 \mathrm{gr}\end{array}$ \\
\hline
\end{tabular}

The moulds of the prepared samples were covered with a glass plate to prevent evaporation. The samples were allowed to stand at room temperature for 24 hours $(23 \pm 2)^{\circ} \mathrm{C}$. And then, they were left for 6 days in an drying oven at $55 \pm 2{ }^{\circ} \mathrm{C}$ without removing the moulds. The samples removed from the oven were left to cool until the room temperature reached. Finally, the compressive strengths of samples were performed in accordance with TS EN 196-1.

\section{Results and Discussions}

\subsection{The Physical Properties, Chemical Compositions and Pozzolanic Activities of Zeolites}

The physical properties, chemical compositions and pozzolanic activity values of natural zeolites are given Table 2. XRD diffraction patterns of zeolites are given Figure 1 and Figure 2.

Table 2 . The physical properties, chemical compositions and pozzolanic activity values of natural zeolites (Cli. denotes clinoptilolite and Anl. denotes analcime)

\begin{tabular}{|c|c|c|c|c|c|}
\hline Chemical & Cli. & Anl. & \multicolumn{3}{|c|}{ Physical properties } \\
\hline $\mathrm{SiO}_{2}$ & 64.70 & 46.71 & & Cli & Anl. \\
\hline $\mathrm{Al}_{2} \mathrm{O}_{3}$ & 11.21 & 17.24 & $\begin{array}{l}\text { Density } \\
\left(\mathrm{g} / \mathrm{cm}^{3}\right)\end{array}$ & 2.11 & 2.28 \\
\hline $\mathrm{Fe}_{2} \mathrm{O}_{3}$ & 1.38 & 9.21 & $\begin{array}{l}\text { Specific } \\
\text { surface } \\
\left(\mathrm{cm}^{2} / \mathrm{g}\right)\end{array}$ & 4079 & 4780 \\
\hline $\mathrm{CaO}$ & 2.08 & 3.03 & \multicolumn{3}{|c|}{ Pozzolanic activity values } \\
\hline $\mathrm{MgO}$ & 0.79 & 5.29 & $\begin{array}{l}\text { TS } 25 \text { limit } \\
\text { values }\end{array}$ & $\mathrm{C}$ & A \\
\hline $\mathrm{Na}_{2} \mathrm{O}$ & 0.38 & 4.84 & $\begin{array}{l}\text { Lime-pozzolan } \\
\text { mix.7daycomp. } \\
\text { strength } \\
>4 \mathrm{MPa}\end{array}$ & 9.02 & 6.30 \\
\hline $\mathrm{K}_{2} \mathrm{O}$ & 3.78 & 4.08 & $\begin{array}{l}\mathrm{SiO}_{2}+\mathrm{Al}_{2} \mathrm{O}_{3} \\
+\mathrm{Fe}_{2} \mathrm{O}_{3}\end{array}$ & 77.30 & 73.16 \\
\hline $\begin{array}{l}\text { Loss of } \\
\text { ignition }\end{array}$ & 11.80 & 7.00 & $\begin{array}{l}\text { wt.content } \\
>\% 70\end{array}$ & & \\
\hline
\end{tabular}

In TS 25, one of the conformity criterias for pozzolans is the 7 day compressive strength of samples prepared with lime-natural pozzolan mixture. The limit value of the compressive strength is at least $4 \mathrm{MPa}$. In experimental studies performed for clinoptilolite and analcime, the average compressive strength values for the lime-zeolite (pozzolan) mixture samples were determined as $9.02 \mathrm{MPa}$ and $6.30 \mathrm{MPa}$, respectively. It has also been emphasized that the sum of $\mathrm{SiO}_{2}+\mathrm{Al}_{2} \mathrm{O}_{3}+\mathrm{Fe}_{2} \mathrm{O}_{3}$ in TS 25 should be at least $70 \%$ by mass. The value of this total was found to be $77.3 \%$ for clinoptilolite and $73.16 \%$ for analcime. At the same time, the specific surfaces of the pozzolans should be greater than $3000 \mathrm{~cm}^{2} / \mathrm{gr}$. The specific surfaces of the pozzolans which is used in this study were found to be $4079 \mathrm{~cm}^{2} / \mathrm{gr}$ for clinoptilolite and $4780 \mathrm{~cm}^{2} / \mathrm{gr}$ for analcime. In 
the pozzolanic activity tests. Because of the specific surfaces of natural zeolites were below of portland cement fineness, the reaction which is between pozzolan and lime was increased. It is thought that, this situation was lead to an increment at the value of pozzolanic activity. These values show that the zeolites used in the study have an usability potential as a pozzolan.

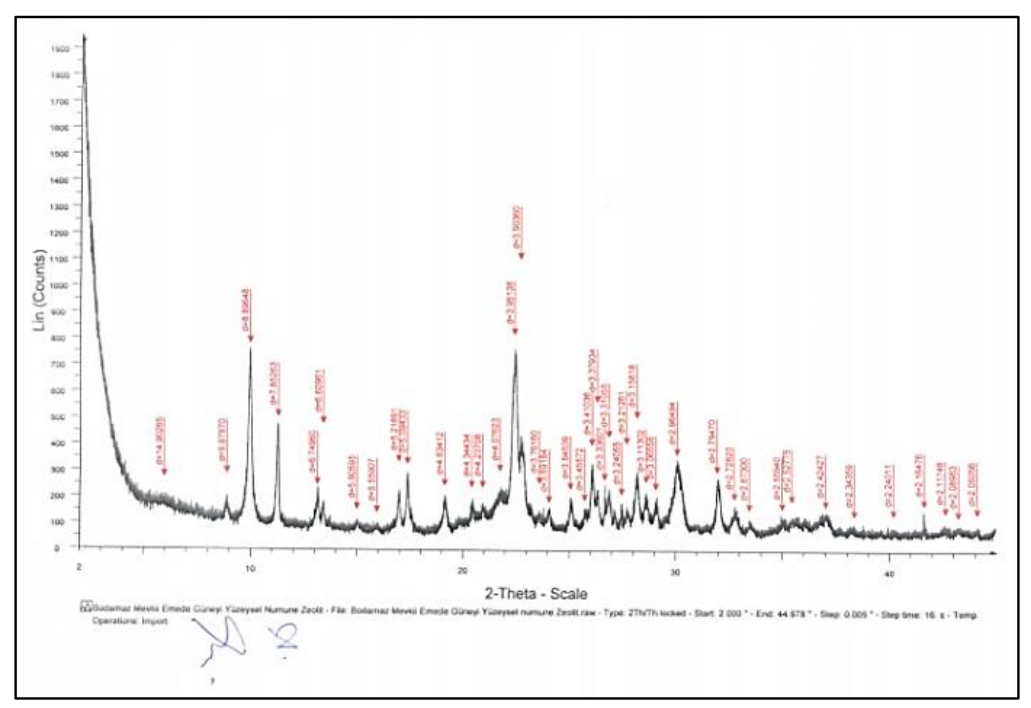

Figure 1. XRD diffraction patterns of clinoptilolite

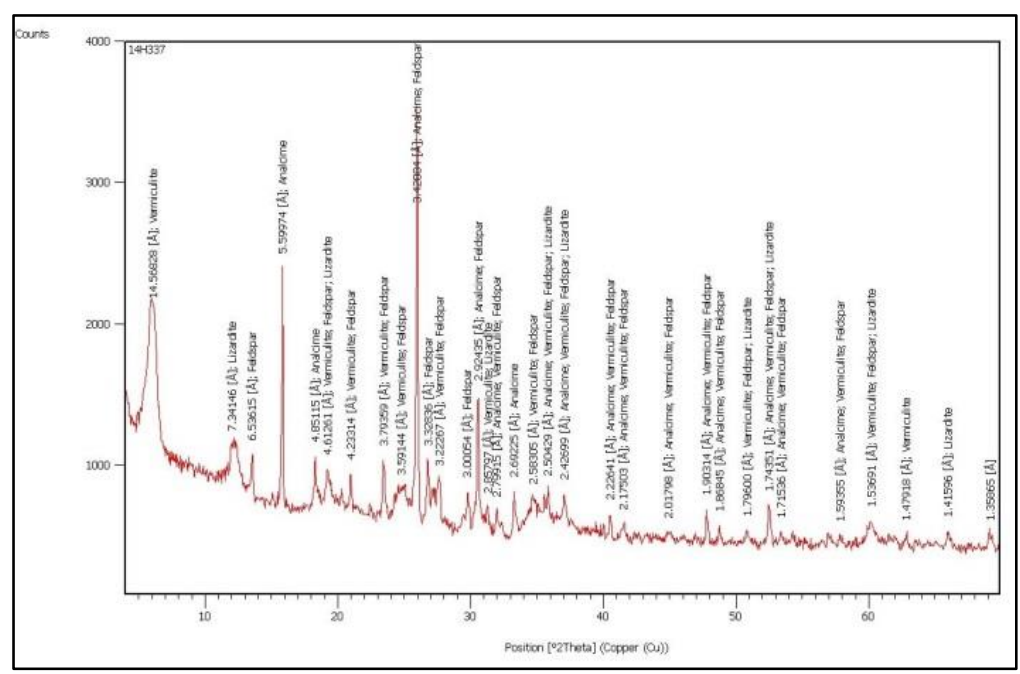

Figure 2. XRD diffraction patterns of analcime

\subsection{Mineralogical Structures of Zeolites}

According to the mineral modal ratios at the mineralogical composition results determined by the X-ray diffraction analysis (XRD) of the clinoptilolite sample, the sample is characterized by zeolite industrial raw material. The modal-mineralogical composition identified as the result of the XRD analysis of the sample is given below. The ratio of clinoptilolite in the sample is $80-85 \%$ (Figure 3). As other minerals; Opal-CT is in a certain ratio, illite mica, quartz and feldspat are low ratios. SEM views obtained using a Scanning Electron Microscope of clinoptilolite were determined with analysis result reports performed by Gördes Zeolite Company. 
$\checkmark$ Clinoptilolite (Silicate-Zeolite Group Mineral) (\%80-85)

$\checkmark$ Opal-CT (Opal-Critobalite/Tridimite) (Silicate-Silica Group Mineral) (10-15\%)

$\checkmark$ Quartz (Silicate-Silica Group Mineral $(\%<2)$

$\checkmark$ Feldspat (Na and K-Felspat) (Silicate-Feldspat Group Mineral) $(\%<2)$

$\checkmark$ İllit-Mica (Silicate-Clay-Mica Group Mineral) $(\%<5)$

The analcime rock is a vitric tuff and consists of glass splinters and crystal components. The glass splinters are converted to zeolite and chlorite, which are heavily altered. Cryptocrystalline silica formations are present in the binder material. The crystalline components are heavily fragmented augite (pyroxene) and very little biotite. Opaque minerals are found in less than $5 \%$ of the rock (Figure 4).

SEM views of analcime were determined by Mineralogy and Petrography Laboratory of General Directorate Of Mineral Research And Explorations. The clinoptilolite and analcime samples confirm the national and international standards required for zeolite applications.

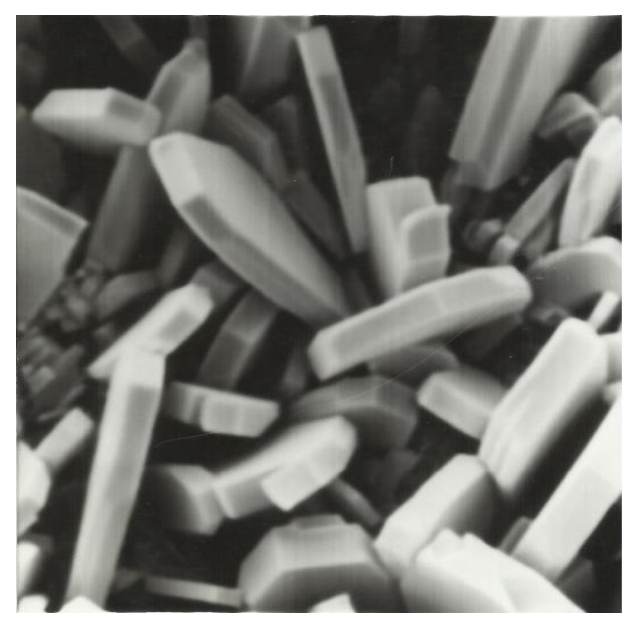

Figure 3. SEM view of clinoptilolite sample

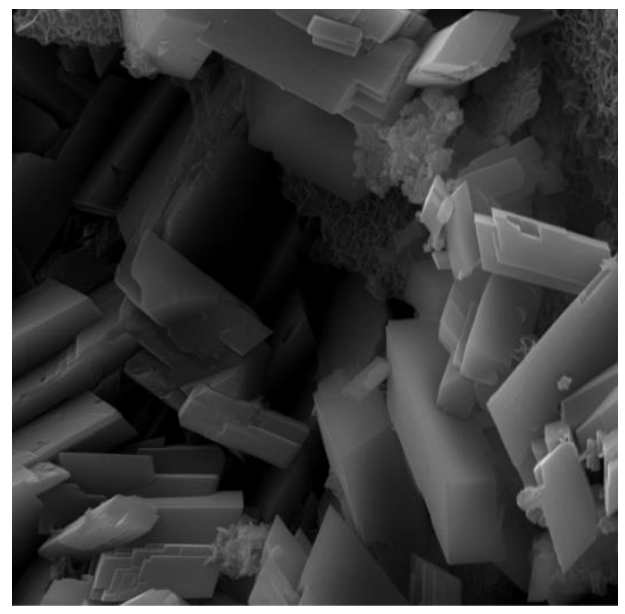

Figure 4. SEM view of analcime sample

When the SEM views of the two zeolites are examined, it is understood that the clinoptilolite and analcime zeolites are in a crystal structure. It is thought that, despite crystal structures of natural zeolites, the reason of exhibit pozzolanic activity is the may be reaction with $\mathrm{Ca}(\mathrm{OH}) 2$ of free silica and alumina components as a result of dissolution at certain scale of the crystal structure in high $\mathrm{pH}$ environment. There are some studies in the literature about the dissolution of crystalline structures in low or high $\mathrm{pH}$ environments of natural zeolites $[16,17]$. 


\section{Conclusions}

1) It has been determined that both natural zeolites (clinoptilolite and analcime) used in the study have potential to be used in sustainable blended cement productions. Due to their favorable qualities such as silicaalumina contents, pozzolanic activity values, low densities, high specific surfaces, glassy structures of rocks and mineralogical structures.

2) The 7-days average compressive strength values of lime-pozzolan mixtures for clinoptilolite and analcime determined by pozzolanic activity tests accordance with TS 25 were $9.02 \mathrm{MPa}$ and $6.30 \mathrm{MPa}$ respectively. Accordingly, the determined compressive strengths are satisfied by TS 25 limit values.

3) The total $\mathrm{SiO}_{2}, \mathrm{Al}_{2} \mathrm{O}_{3}$ and $\mathrm{Fe}_{2} \mathrm{O}_{3}$ contents of the natural zeolites used in the study are similar to some pozzolanic materials used in the cement industry. The value of this total was found to be $77.3 \%$ for clinoptilolite and $73.16 \%$ for analcime. The determined total content values are satisfied by TS 25 limit values.

4) In the result of this study conducted to determinate the puzolanic activity of analcime and to investigate whether it has potential availability in sustainable blended cement production. It is thought that analcime which is the second valuable mineral of natural zeolites may be an alternative to clinoptilolite, which is more widely used in the construction industry. It is also thought that energy-saving, economical and environmentfriendly solutions will be obtained due to using less portland cement in cement production. But, it should not be forgotten that, this result may become more certainty after tests for strength and durability on analcimes which will be obtained from different regions.

\section{Acknowledgements}

This study was funded by the Scientific Research Project Unit of Ordu University under Project No: TF-1521. Also, we would like to thanks to General Directorate Of Mineral Research And Explorations, Votorantim Cimentos, Mineralogy Laboratory of Blacksea Technical University, Gördes Zeolite Company for their support and assistance.

\section{References}

[1] Erdoğan, T. Y., Beton, METU Press, Ankara, 757s., 2013.

[2] Massazza F., "Pozzolanic Cement", Cement and Concrete Composites, v:15, pp: 185-214, 1993.

[3] ASTM C 311, Standard test methods for sampling and testing fly ash or natural pozzolans for use a mineral admixture in portland-cement concrete, Annual book of ASTM standards, 1994.

[4] TS EN 450, Fly ash for concrete-Part 1: Definition, specifications and conformity criteria, Turkish Standarts Institute, Ankara, 2013.

[5] TS 25, Natural pozzolan (trass) for use in cement and concrete-Definitions, requirements and conformity criteria, Turkish Standarts Institute, Ankara, 2008.

[6] Kılınçkale F.M., "Çeşitli puzolanların puzolanik aktivitesi ve bu puzolanlarla üretilen harçların dayanımı", Chamber of Civil Engineers, Journal of Technical, pp: 1217-1229, 1996.

[7] Chan SYN, Ji X. Comparative study of the initial surface absorption and chloride diffusion of high performance zeolite, silica fume and PFA concretes. Cem Concr Compos. 1999; 21:293-300.

[8] Trnı'k, A., Scheinherrova', L., Medved, I., Cerny, R., "Simultaneous DSC and TG analysis of highperformance concrete containing natural zeolite as a supplementary cementitious material", J Therm. Anal. Calorim., 121:67-73, 2015.

[9] Kumbasar, I., Silika mineralleri, Press of Istanbul Technical University, Istanbul, 1977.

[10] Yazıcıoğlu, Ö.F., "Investigation of usability as pozzolanic additive material of natural zeolite (analcime) in sustainable productions of cement and Concrete industry", MSc. Thesis, University of Ordu, Institute for Graduate Studies in Science and Technology, Department of Renewable Energy, 85p, 2016.

[11] Akgün, Y., Yazıcığlu, Ö.F.,“ The effect of two different natural zeolite additions on the abrasion resistance of cement mortar“, Ordu University, Journal of Science and Technology, Vol:6, No: 1, 94-104, 2016. 
[12] ASTM C 430, Test method for fineness of hydraulic cement by the 45- $\mu \mathrm{m}$ (No. 325) sieve, American Society for Testing and Materials, United States of America, 2005.

[13] TS EN 196-1, Methods of testing cement - Part 1: Determination of strength, Turkish Standarts Institute, Ankara, 2016.

[14] TS EN 197-1, Cement - Part 1: Composition, specification and conformity criteria for common cements, Turkish Standarts Institute, Ankara, 2012.

[15] TS 196-6, Methods of testing cement - Part 6: Determination of fineness, Turkish Standarts Institute, Ankara, 2010.

[16] Yamamoto, S., Sugiyama, S. , Matsuoka, O., Kohmura, K., Honda, T., Banno, Y., Nozoye, H., Dissolution of Zeolite in Acidic and Alkaline Aqueous Solutions As Revealed by AFM Imaging, Journal of Physical Chemistry 100, pp:18474-18472, 1996.

[17] Cizmek, A., Subotic, B., Smit, I., Tonejc, A., Aiello, R., Crea, F., Nastro, A., Dissolution of high-silica zeolites in alkaline solutions II. Dissolution of 'activated' silicate-1 and ZSM-5 with different aluminum content, Microporous Materials 8, pp:159-169, 1997. 